\title{
Morphological Characterization and Genetic Variability Studies in Bottle Gourd [Lagenaria siceraria (Mol.) Standley.]
}

\author{
E. Rambabu ${ }^{1}$, A.R. Mandal ${ }^{1}$, P. Hazra ${ }^{1}$, B.K. Senapati ${ }^{2}$ and U. Thapa ${ }^{1}$ \\ ${ }^{1}$ Department of Vegetable Science, ${ }^{2}$ Department of Genetics and Plant Breeding \\ Bidhan Chandra Krishi Viswavidyalaya, Mohanpur-741252, Nadia, West Bengal, India \\ *Corresponding author
}

\section{A B S T R A C T}

\begin{tabular}{|l|}
\hline Ke y w o r d s \\
Qualitative traits, \\
Quantitative traits, \\
Variability, \\
Heritability and \\
Genetic advance.
\end{tabular}

The present investigation was carried out at Horticultural Research Station, Mondouri, Bidhan Chandra Krishi Viswavidyalaya, Mohanpur, Nadia, West Bengal, India during spring summer seasons of 2015, 2016 and 2017 in a Randomized Block Design with three replications. The morphological characterization was done as per minimal descriptors of NBPGR developed for bottle gourd. The results revealed that the greatest diversity was observed in fruit characters especially fruit shape and fruit colour among the genotypes for various characters studied. Analysis of variance revealed significant differences among genotypes for all the characters. In general PCV was marginally higher than the corresponding GCV indicated the less influence of environment in the expression of the characters under study. High heritability coupled with high genetic advance as percentage of mean was observed for vine length, number of primary branches, days to first male flower appearance, days to first female flower appearance, days to first harvest, number of fruits per plant, average fruit weight, fruit length, fruit width, fruit yield per plant, sex ratio, seed number per fruit, 100 seed weight, TSS of the pulp, total sugar content and ascorbic acid content of the pulp indicated that these characters were mainly controlled by additive gene effects and thus selection may be effective.

\section{Introduction}

Cucurbitaceous vegetables are the largest family consisting of maximum number of edible species in vegetable kingdom. Bottle gourd is botanically known as Lagenaria siceraria (Mol.) Standley. and its chromosome number is $2 \mathrm{n}=22$ is one such important vegetable of this family with high genetic diversity for fruit shape and other fruit characteristics, resulting in a variety of uses (Bisognin, 2002). Telangana region in India is endowed with a rich variability of bottle gourd, especially with regard to fruit characteristics (Sivaraj and Pandravada, 2005). Morphological characters are useful for characterizing genotypes against highly heritable and stable traits. Further, association of any morphological character with desirable traits or yield components serves as a phenotypic marker in the selection process. The objective of this study is to determine the magnitude of genetic variability, heritability and genetic advance that could be realized through selection. The information obtained from this study would be helpful to specify certain traits that could be used as selection indices for identifications of potentially high yielding bottle gourd genotypes. 


\section{Materials and Methods}

The experimental material consisted of twenty one genotypes were laid out in a Randomized Block Design (RBD) with three replications at Horticultural Research Station, Mondouri, Bidhan Chandra Krishi Viswavidyalaya, Mohanpur, Nadia, West Bengal, India during spring summer seasons of 2015, 2016 and 2017. Each genotype was represented by a double row plot of $5 \mathrm{~m}$ length with 10 plants sown at a distance of $3 \mathrm{~m}$ between rows and 1 $\mathrm{m}$ between plants. Observations were recorded from five randomly selected plants for all the quantitative characters except days to first male flower appearance, days to first female flower appearance and 100 seed weight. Data on qualitative parameters was recorded on whole plot basis. The data on qualitative and quantitative characters were recorded as per minimal descriptors of NBPGR developed for bottle gourd. TSS content of the pulp was determined by an ERMA Hand Refractometer. The sugar content of the pulp was estimated by following anthrone method as per Dubois et al. (1956). Ascorbic acid content of the pulp was determined by 2, 6-dichlorophenol indophenol titration method (Ranganna, 1986).

For statistical analysis, Analysis of variance was done based on RBD as suggested by Snedecor and Cochran (1937) and reviewed by Panse and Sukhatme (1967) for each of the characters separately. Genetic parameters, genotypic, environmental and phenotypic coefficients of variation (expressed in percentage) were calculated by using the formula given by Burton (1952). Heritability in broad sense was determined according to the methodology given by Allard (1960). The estimate of the expected genetic advance (GA) expressed as a percentage of the mean was computed by the formula given by Johnson et al. (1955).

\section{Results and Discussion}

The results on morphological characters of bottle gourd are presented in table 1. The qualitative characters including fruit stem shape, tendril, tendril branching, leaf margin, leaf shape, sex type and flower colour were constant for all accessions. This was consistent with the results of Huh et al. (2008) on Korean and Turkish watermelon populations and Aruah et al. (2010) on variations among some Nigerian Cucurbita landraces. The greatest diversity was observed in fruit characters especially fruit shape, fruit colour and inflorescence type. This concurs to the findings of Bisognin (2002) who reported that cucurbits are very similar in above ground development but have high genetic diversity for fruit shape and other fruit characteristics.

The analyses of variance for sixteen characters of twenty one genotypes of bottle gourd are presented in table 2. Highly significant differences were observed among the genotypes for all the characters indicating presence of large amount of variability in all the characters studied. These findings are in general agreement with the findings of Pandit et al. (2009) and Bhardwaj et al. (2013) in bottle gourd.

The phenotypic variance $\left(\sigma^{2} \mathrm{p}\right)$ and phenotypic coefficient of variation (PCV) were slightly higher than corresponding genotypic variance $\left(\sigma^{2} g\right)$ and genotypic coefficient of variation (GCV) for most of the characters indicated the presence of less environmental effect upon the concerned characters. The genetic parameters viz., genotypic and phenotypic coefficients of variation, heritability in broad sense and genetic advance along with mean and range of different characters are presented in table 3. High magnitude of GCV as well as PCV were recorded for traits viz., fruit length (38.07 and 40.34), fruit width (37.11 and $37.92)$, vine length (30.26 and 30.85), fruit 
yield per plant (25.50 and 26.00), sex ratio (23.16 and 23.96), number of fruits per plant (22.39 and 23.23), number of primary branches (21.78 and 22.71), seed number per fruit (20.85 and 21.23) and average fruit weight (20.57 and 21.04). Moderate GCV and PCV were recorded for TSS of the pulp (14.12 and 15.21), 100 seed weight (13.70 and 13.87), total sugar content of the pulp (13.35 and 13.75), Ascorbic acid content of the pulp (12.55 and 12.64), days to first harvest (11.57 and 11.94), days to first male flower appearance (10.69 and 10.98) and days to first female flower appearance (10.44 and 10.77), suggested existence of considerable variability in the population. Selection for these traits may also be given the importance for improvement programme. Similar findings were also reported earlier in bottle gourd by Munshi and Acharyya (2005), Gayen and Hossain (2006), Pandit et al. (2009), Bhardwaj et al. (2013), Sharma and Sengupta (2013) and Mangala et al. (2015).

In the present investigation high magnitude of heritability was recorded for all the characters under the study. The highest heritability was recorded for 100 seed weight $(98.0 \%)$ and ascorbic acid content of the pulp (98.0\%) followed by vine length (96.0\%), average fruit weight (96.0\%), fruit width (96.0\%), fruit yield per plant $(96.0 \%)$ and seed number per fruit $(96.0 \%)$, days to first male flower appearance $(95.0 \%)$, days to first female flower appearance $(94.0 \%)$, days to first fruit harvest $(94.0 \%)$, total sugar content of the pulp (94.0\%) and number of fruits per plant $(93.0 \%)$ and sex ratio $(93.0 \%)$, number of primary branches $(92.0 \%)$, fruit length $(89.90 \%)$ and TSS of the pulp (86.0\%). Similar high heritability for all the traits was also reported Munshi and Acharyya (2005) and Bhardwaj et al. (2013).

Genetic advance as percentage of mean was observed high for all the characters under the study viz., fruit width $(74.79 \%)$, fruit length
(74.03\%), vine length $(61.15 \%)$, fruit yield per plant $(51.51 \%)$, sex ratio (46.12\%), number of fruits per plant $(44.44 \%)$, number of primary branches (43.02\%), seed number per fruit $(42.18 \%)$, average fruit weight (41.44\%), 100 seed weight (27.86\%), TSS of the pulp (27.00\%), total sugar content of the pulp $(26.69 \%)$, ascorbic acid content of the pulp $(25.64 \%)$, days to first harvest $(23.09 \%)$, days to first male flower appearance $(21.43 \%)$ and days to first female flower appearance $(20.83 \%)$.

Heritability estimates along with genetic advance are more useful than the heritability value alone for selecting the best individual. High heritability coupled with high genetic advance as percentage of mean was observed for vine length, number of primary branches, days to first male flower appearance, days to first female flower appearance, days to first harvest, number of fruits per plant, average fruit weight, fruit length, fruit width, fruit yield per plant, sex ratio, seed number per fruit, 100 seed weight, TSS of the pulp, total sugar content of the pulp and ascorbic acid content of the pulp indicated that these characters were mainly controlled by additive gene effects and thus selection may be rewarding for the further improvement of these traits. These findings are in general agreement with the findings of various workers in bottle gourd for various quantitative traits like, for vine length, number of primary branches and yield per plant by Bhardwaj et al. (2013); for all the characters studied by Sharma and Sengupta (2013); for days to first male flowering and female flowering by Husna et al. (2014); for node number at first female flower, sex ratio, fruit length, fruit girth, number of fruits per plant and fruit yield per plant by Mangala $e t$ al. (2015) and for total fruit yield per plant, number of primary branches, number of fruits per plant and average fruit weight by Aashish et al. (2016). 
Table.1 Different qualitative characters on plant morphology of 21 genotypes in bottle gourd

\begin{tabular}{|c|c|c|c|c|c|c|c|c|c|c|c|c|}
\hline $\begin{array}{l}\text { Sl. } \\
\text { NO }\end{array}$ & Genotypes & $\begin{array}{l}\text { Stem } \\
\text { shape }\end{array}$ & $\begin{array}{l}\text { Tendri } \\
\text { l }\end{array}$ & $\begin{array}{l}\text { Tendri } \\
\text { l type }\end{array}$ & $\begin{array}{l}\text { Tendril } \\
\text { branchin } \\
\text { g }\end{array}$ & $\begin{array}{l}\text { Leaf } \\
\text { margi } \\
\text { n }\end{array}$ & $\begin{array}{l}\text { Leaf } \\
\text { shape }\end{array}$ & $\begin{array}{l}\text { Sex } \\
\text { type }\end{array}$ & $\begin{array}{l}\text { Flowe } \\
\mathbf{r} \\
\text { colour }\end{array}$ & $\begin{array}{l}\text { Inflorescenc } \\
\text { e type }\end{array}$ & $\begin{array}{l}\text { Fruit } \\
\text { shape }\end{array}$ & $\begin{array}{l}\text { Fruit } \\
\text { colour }\end{array}$ \\
\hline 1 & 2013/BOGVAR-1 & Angular & Present & Coiled & Branched & Entire & Cordate & Monoecious & Cream & Single & Club & Green \\
\hline 2 & 2013/BOGVAR-2 & Angular & Present & Coiled & Branched & Entire & Cordate & Monoecious & Cream & Single & Cylindrical & Whitish green \\
\hline 3 & 2013/BOGVAR-3 & Angular & Present & Coiled & Branched & Entire & Cordate & Monoecious & Cream & Single & Elongate straight & Green \\
\hline 4 & 2013/BOGVAR-4 & Angular & Present & Coiled & Branched & Entire & Cordate & Monoecious & Cream & Single & Round & Light green \\
\hline 5 & 2013/ NDBG-104 & Angular & Present & Coiled & Branched & Entire & Cordate & Monoecious & Cream & Single & Elongate straight & Green \\
\hline 6 & Pusa Samridhi & Angular & Present & Coiled & Branched & Entire & Cordate & Monoecious & Cream & Single & Elongate straight & Green \\
\hline 7 & Pusa Santusti & Angular & Present & Coiled & Branched & Entire & Cordate & Monoecious & Cream & Single & Pyriform & Green \\
\hline 8 & Pusa Sandesh & Angular & Present & Coiled & Branched & Entire & Cordate & Monoecious & Cream & Single & Round (Oblate) & Light green \\
\hline 9 & Pusa Naveen & Angular & Present & Coiled & Branched & Entire & Cordate & Monoecious & Cream & Single & Cylindrical & Green \\
\hline 10 & Arka Bahar & Angular & Present & Coiled & Branched & Entire & Cordate & Monoecious & Cream & Single & Elongate straight & Light green \\
\hline 11 & Punjab Komal & Angular & Present & Coiled & Branched & Entire & Cordate & Monoecious & Cream & Single & Oval & Light green \\
\hline 12 & Punjab Long & Angular & Present & Coiled & Branched & Entire & Cordate & Monoecious & Cream & Single & Cylindrical & Whitish green \\
\hline 13 & Punjab Barkat & Angular & Present & Coiled & Branched & Entire & Cordate & Monoecious & Cream & Single & Elongate straight & Green \\
\hline 14 & Bankura Local-1 & Angular & Present & Coiled & Branched & Entire & Cordate & Monoecious & Cream & Single & Club & Patchy dark green \\
\hline 15 & Ganga Jamuna & Angular & Present & Coiled & Branched & Entire & Cordate & Monoecious & Cream & Single & Oval & Green \\
\hline 16 & Bankura Local-2 & Angular & Present & Coiled & Branched & Entire & Cordate & Monoecious & Cream & Single & Oval & Green \\
\hline 17 & Deb Jyoti & Angular & Present & Coiled & Branched & Entire & Cordate & Monoecious & Cream & Double & Oval & Light green \\
\hline 18 & Gutka Long & Angular & Present & Coiled & Branched & Entire & Cordate & Monoecious & Cream & Single & Elongate curved & Green \\
\hline 19 & Lau Chameli & Angular & Present & Coiled & Branched & Entire & Cordate & Monoecious & Cream & Single & Oval & Patchy green \\
\hline 20 & RNLS-118 & Angular & Present & Coiled & Branched & Entire & Cordate & Monoecious & Cream & Single & Elongate curved & Green \\
\hline 21 & RNLS-140 & Angular & Present & Coiled & Branched & Entire & Cordate & Monoecious & Cream & Single & Elongate straight & Green \\
\hline
\end{tabular}


Table.2 Analysis of variance for 16 quantitative traits in 21 genotypes of bottle gourd

\begin{tabular}{|c|c|c|c|c|}
\hline \multirow{2}{*}{$\begin{array}{c}\text { S. } \\
\text { No }\end{array}$} & \multirow[b]{2}{*}{ Character } & \multicolumn{3}{|c|}{ Mean sum of squares } \\
\hline & & $\begin{array}{c}\text { Replications } \\
(\mathbf{d f}=2)\end{array}$ & $\begin{array}{l}\text { Treatments } \\
(\mathbf{d f}=\mathbf{2 0})\end{array}$ & $\begin{array}{c}\text { Error } \\
(\mathrm{df}=\mathbf{4 0})\end{array}$ \\
\hline 1. & Vine length (m) & 0.1652 & $9.6771 * *$ & 0.1250 \\
\hline 2. & Number of primary branches & 0.1965 & $3.9548 * *$ & 0.1121 \\
\hline 3. & Days to first male flower appearance & 0.0763 & $79.3199 * *$ & 1.4514 \\
\hline 4. & Days to first female flower appearance & 2.9348 & $101.4898 * *$ & 2.1666 \\
\hline 5. & Days to first harvest & 7.4462 & $196.4981 * *$ & 4.1947 \\
\hline 6. & Number of fruits per plant & 0.0065 & $5.4651 * *$ & 0.1368 \\
\hline 7. & Average fruit weight $(\mathrm{kg})$ & 0.0008 & $0.1787 * *$ & 0.0027 \\
\hline 8. & Fruit length $(\mathrm{cm})$ & 13.6589 & $515.9526 * *$ & 20.2417 \\
\hline 9. & Fruit width $(\mathrm{cm})$ & 1.2579 & $69.8624 * *$ & 1.0219 \\
\hline 10. & Fruit yield per plant (kg) & 0.0430 & $9.5078 * *$ & 0.1251 \\
\hline 11. & Sex ratio $(\mathrm{M} / \mathrm{F})$ & 0.1181 & $10.0434 * *$ & 0.2297 \\
\hline 12. & Seed number per fruit & 228.7799 & $27094.00 * *$ & 329.4271 \\
\hline 13. & 100 seed weight $(\mathrm{g})$ & 0.0038 & $12.3390 * *$ & 0.1041 \\
\hline 14. & Total soluble solids of the pulp $\left({ }^{0} \mathrm{Brix}\right)$ & 0.0006 & $0.7198 * *$ & 0.0366 \\
\hline 15. & Total sugar content of the pulp (\%) & 0.0202 & $0.3684 * *$ & 0.0073 \\
\hline 16. & Ascorbic acid content of the pulp ( $\mathrm{mg} / 100 \mathrm{~g})$ & 0.0324 & $3.3806 * *$ & 0.0177 \\
\hline
\end{tabular}


Table.3 Estimates of variability, heritability and genetic advance as per cent of mean for 16 quantitative characters in 21 genotypes of bottle gourd

\begin{tabular}{|c|c|c|c|c|c|c|c|c|c|c|c|}
\hline \multirow{2}{*}{$\begin{array}{l}\text { S. } \\
\text { No. }\end{array}$} & \multirow{2}{*}{ Character } & \multicolumn{2}{|c|}{ Range } & \multirow{2}{*}{ Mean } & \multicolumn{2}{|c|}{ Variance } & \multirow{2}{*}{$\begin{array}{c}\text { PCV } \\
(\%)\end{array}$} & \multirow{2}{*}{$\begin{array}{c}\text { GCV } \\
(\%)\end{array}$} & \multirow{2}{*}{$\begin{array}{l}\mathbf{h}^{2} \\
(\%)\end{array}$} & \multirow{2}{*}{$\begin{array}{l}\text { Genetic } \\
\text { Advance }\end{array}$} & \multirow{2}{*}{$\begin{array}{c}\text { GA as per } \\
\text { cent of } \\
\text { mean }\end{array}$} \\
\hline & & Minimum & Maximum & & Phenotypic & Genotypic & & & & & \\
\hline 1 & Vine length (m) & 3.26 & 9.98 & 5.90 & 3.31 & 3.18 & 30.85 & 30.26 & 96.00 & 3.61 & 61.15 \\
\hline 2 & Number of primary branches & 3.90 & 7.83 & 5.20 & 1.39 & 1.28 & 22.71 & 21.78 & 92.00 & 2.24 & 43.02 \\
\hline 3 & DF male flower appearance & 41.40 & 56.30 & 47.66 & 27.41 & 25.96 & 10.98 & 10.69 & 95.00 & 10.21 & 21.43 \\
\hline 4 & DF female flower appearance & 47.30 & 64.90 & 55.13 & 35.27 & 33.11 & 10.77 & 10.44 & 94.00 & 11.48 & 20.83 \\
\hline 5 & Days to first harvest & 51.20 & 81.63 & 69.20 & 68.30 & 64.10 & 11.94 & 11.57 & 94.00 & 15.98 & 23.09 \\
\hline 6 & Number of fruits per plant & 3.92 & 8.09 & 5.95 & 1.91 & 1.78 & 23.23 & 22.39 & 93.00 & 2.65 & 44.44 \\
\hline 7 & Average fruit weight $(\mathrm{kg})$ & 0.77 & 1.61 & 1.18 & 0.06 & 0.08 & 21.04 & 20.57 & 96.00 & 0.49 & 41.44 \\
\hline 8 & Fruit length $(\mathrm{cm})$ & 13.71 & 56.50 & 33.76 & 185.48 & 165.24 & 40.34 & 38.07 & 89.00 & 24.99 & 74.03 \\
\hline 9 & Fruit width $(\mathrm{cm})$ & 6.80 & 23.27 & 12.91 & 23.97 & 22.95 & 37.92 & 37.11 & 96.00 & 9.66 & 74.79 \\
\hline 10 & Fruit yield per plant (kg) & 3.20 & 9.67 & 6.94 & 3.25 & 3.13 & 26.00 & 25.50 & 96.00 & 3.57 & 51.51 \\
\hline 11 & Sex ratio $(\mathrm{M} / \mathrm{F})$ & 5.20 & 12.16 & 7.81 & 3.50 & 3.27 & 23.96 & 23.16 & 93.00 & 3.60 & 46.12 \\
\hline 12 & Seed number per fruit & 311.78 & 697.03 & 453.01 & 9250.95 & 8921.52 & 21.23 & 20.85 & 96.00 & 191.08 & 42.18 \\
\hline 13 & 100 seed weight (g) & 10.71 & 19.73 & 14.75 & 4.18 & 4.08 & 13.87 & 13.70 & 98.00 & 4.11 & 27.86 \\
\hline 14 & TSS of the pulp ( ${ }^{0}$ Brix $)$ & 2.60 & 4.20 & 3.38 & 0.26 & 0.23 & 15.21 & 14.12 & 86.00 & 0.91 & 27.00 \\
\hline 15 & Total sugar $(\%)$ & 1.38 & 3.04 & 2.60 & 0.13 & 0.12 & 13.75 & 13.35 & 94.00 & 0.69 & 26.69 \\
\hline 16 & Ascorbic acid (mg/100 g) & 6.06 & 10.09 & 8.44 & 1.14 & 1.12 & 12.64 & 12.55 & 98.00 & 2.16 & 25.64 \\
\hline
\end{tabular}


The present investigation revealed that the morphological characters are useful for characterizing genotypes against highly heritable and stable traits. Further, association of any qualitative character with desirable traits or yield components serves as a phenotypic marker in the selection process. On the basis of this study, it can be concluded that selection would be rewarding for fruit length, fruit width, vine length, fruit yield per plant, sex ratio, number of fruits per plant, number of primary branches, seed number per fruit and average fruit weight in bringing out the improvement in the bottle gourd because they appeared with high value of GCV, PCV, heritability and genetic gain.

\section{References}

Aashish, V.V., Singh, P.K., Mallikarjunarao, k., Kouser, P.W. and Saran, R. 2016. Genetic variability, heritability and genetic advance studies in bottle gourd. Ecology, Environment and Conservation Paper. 22: 87-90.

Allard, R.W. 1960. Principles of Plant Breeding. John Wiley and Sons, Inc., New York. pp. 227-228.

Aruah, C.B., Uguru, M.I. and Oyiga, B.C. 2010. Variations among some Nigerian Cucurbita landraces. African Journal of Plant Science. 4(10): 374-86

Bhardwaj, D.R., Singh, A. and Singh, U. 2013. Genetic variability of bottle gourd (Lagenaria siceraria (Mol.) Standl.) by multivariate analysis. In: Proc. of National symposium on abiotic and biotic stress management in vegetable crops. Indian Society of Vegetable Science. pp., 370.

Bisognin, D.A. 2002. Origin and evolution of cultivated cucurbits. Ciencia Rural. 32(5): 715-23.

Burton, G.W. 1952. Quantitative inheritance in grasses. Proc. 6th International Grassland Congress. 1: 277-283.
Dubois, M., Gilles, K.A., Hamilton, J.K., Robers, P.A. and Smith, F. 1956. A colorimetric method for the determination of sugar. Analytical Chemistry. 28: 350-356.

Gayen, N. and Hossain, M. 2006. Study of heritability and genetic advance in bottle gourd (Lagenaria siceraria (Mol.) Standl.). Journal of Interacademicia. 10(4): 463-466.

Huh, Y.C., Solmaz, I. and Sari, N. 2008. Morphological characterization of Korean and Turkish watermelon germplasm. (In) Proceedings of the 9th EUCARPIA meeting on Genetics and Breeding of Cucurbitaceae. Pitrat $M$ (ed.). INRA, Avignon (France), 21 May 2008.

Husna, A.M., Maih, A., Begum, S., Shilpi, S.Z. and Islam, M.R. 2014. Genetic Variability, Correlation and Path coefficient analysis based on vegetative characters in bottle gourd (Lagenaria siceraria (Mol.) Standl.). Advance in Agriculture and Biology. 2(1): 8-12.

Johnson, H.W., Robinson, H.F. and Comstock, R.E. 1955. Estimates of genetic and environmental variability of Soybean. Agronomy Journal. 47: 314318.

Mangala, T., Mandal, J. and Dhangrah, V.K. 2015. Studies on genetic variability and trait inter relationship in bottle gourd (Lagenaria siceraria (Mol.) Standl). Hort Flora Research Spectrum. 4(1): 3438.

Munshi, R. and Acharya, P. 2005. Varietal evaluation in bottle gourd genotypes. Ind. Agric. 49(3/4): 213-221.

Pandit, M.K., Mahato, B. and Sarkar, A. 2009. Genetic variability, heritability and genetic advance for some fruit character and yield in bottle gourd (Lagenaria siceraria (Mol.) Standl.). Acta Horticulturae. 809: 221-225. 
Panse, V.G. and Sukhatme, P.V. 1967. Statistical Methods for Agricultural Workers. Indian Council of Agricultural Research, New Delhi.

Ranganna, S. 1986. Hand Book of Analysis and Quality Control for Fruit and Vegetable Products Chapter No: 5, Pages. 106-109

Sharma, A. and Sengupta, S.K. 2013. Genetic diversity, heritability and morphological characterization in bottle gourd
(Lagenaria siceraria (Mol.) Standl.). The Bioscan. 8(4): 1461-1465.

Sivaraj, N. and Pandravada, S.R. 2005. Morphological diversity for fruit characters in bottle gourd germplasm from tribal pockets of Telangana region of Andhra Pradesh, India. Asian AgriHistory, 9: 305-310.

Snedecor, G.W. and Cochran, W.G. 1937. Statistical Methods. Iowa State University Press, Ames

\section{How to cite this article:}

Rambabu, E., A.R. Mandal, P. Hazra, B.K. Senapati and Thapa, U. 2017. Morphological Characterization and Genetic Variability Studies in Bottle Gourd [Lagenaria siceraria (Mol.) Standley.]. Int.J.Curr.Microbiol.App.Sci. 6(9): 3585-3592. doi: https://doi.org/10.20546/ijcmas.2017.609.440 